\title{
COPYING STRATEGIES IN THE MANUSCRIPT DISSEMINATION OF LUIGI BOCCHERINI'S TRIOS OPUS 1
}

\author{
RUDOLF RASCH \\ Universiteit Utrecht
}

\begin{abstract}
Izvleček: V skoraj šestdesetih znanih rokopisih najdemo enega ali več Boccherinijevih Triov op. 1, ki jih je napisal leta 1760. Videti je, da so prepisovalci lahko pri svojem delu sledili različnim načelom: lahko so ustvarjali različice in napake, a tudi popravke, izboljšave, revizije ali celo priredbe.
\end{abstract}

Ključne besede: Luigi Boccherini, glasbeni kopisti.

\begin{abstract}
Nearly sixty extant manuscripts contain one or more of Boccherini's six Trios op. 1 composed in 1760. It appears that copyists could follow different procedures when copying a work: they could create variants and errors, but also corrections, improvements, revisions and even arrangements.
\end{abstract}

Keywords: Luigi Boccherini, manuscript copying.

Today Boccherini's Trios opus 1, composed in 1760, are not the composer's best-known works. ${ }^{1}$ Nevertheless, they belong to the works by him most widely disseminated in the eighteenth century. Nearly sixty extant manuscripts from before 1830 contain one or more of the six works. The sheer number of these manuscripts poses many problems to the modern researcher. But it is a blessing in disguise as well: it allows us to study the ways in which copyists in the eighteenth century carried out their task. Did they simply copy their examples; did they commit errors; or did they introduce variants? And did they apply corrections, changes, revisions or improvements?

No autographs of Boccherini's Trios op. 1, nor any copies close to an autograph, are preserved. There is no authorized early edition. The first edition, Sei trietti per due violini e basso [...] Opera II (Paris: Bailleux, 1767), was based on a manuscript in circulation, and all later editions follow this edition. This means that in order to present a critical text of the works - as I had to do for the Opera Omnia published by Ut Orpheus in Bologna for the Centro Studi Opera Omnia Luigi Boccherini - it was necessary to have a good understanding of both the manuscript and the printed traditions of the works. ${ }^{2}$

1 The works are G. 77-82 in Gérard, Thematic, Bibliographical and Critical Catalogue, 77-87.

2 A critical edition is now available: Boccherini, Sei Trii. 
In order to bring some system to the source situation a simple classificatory model will be used here. This model distinguishes five categories of sources: the original version; pre-publication manuscripts; authorized editions; unauthorized editions; and post-publication manuscripts. The original version includes the composer's own autograph archival manuscript and autograph or authorized copies of this manuscript: in short, manuscript sources that, one can be sure, reflect the composer's intentions. Unfortunately, as already noted, for Boccherini's Trios op. 1 no such manuscripts have come down to us.

Pre-publication manuscripts are manuscripts copied directly or indirectly from the original version, without the intervention of an edition. The designation "pre-publication" does not imply that they were all written before the first edition. They may actually postdate the first edition or even later editions. The designation implies only that no edition was included in the chain of copying leading from the original version to the manuscript in question. Pre-publication manuscripts may contain all the works of a particular set; or just one; or a few; or several, but not all, of them.

Editions are printed publications of the works. Editions may be either authorized (based on a score provided by the composer and produced with his consent) or unauthorized (where the publisher works from a score acquired independently by him, thus bypassing the composer).

Post-publication manuscripts are manuscripts that are either copied from an edition (authorized or not) or copied from another post-publication manuscript. In most cases, they contain the complete contents of the edition on which they are based and follow that edition in all details.

With the categories now described, it is possible to classify all known sources of Boccherini's Trios op. 1. As already remarked, no original versions are known. But there are apparently no fewer than 49 extant manuscripts containing one or more of Boccherini's six Trios op. 1, that may be considered pre-publication manuscripts. The category editions comprises the five known early editions, one of which was reissued twice by later publishers under new imprints. In the case of Boccherini's Trios op. 1 ten post-publication manuscripts copied directly or indirectly from one of the editions can be identified.

The various sources are listed in Appendix 2 to this article. They are all provided with brief codes in bold face that will be used for reference in the text of this article.

\section{The Variability of the Sources}

As may have been sensed already from the introduction, the available sources for Boccherini's Trios op. 1 show a great, if not bewildering, variety. This variety concerns nearly all aspects of the sources as such, and also of the compositions as they are presented in the sources.

Source Types. The sources can be divided into various types. An obvious distinction is that between sources in score and ones in separate parts. Scores are rare and occur only in manuscript form (Gel, MC, Dr).

Sources in separate parts may either write all the Trios one after another in the various parts or take the form of sets of manuscripts, with separate gatherings for all the individual pieces. Sets may be either complete or incomplete. Some sets of manuscripts are ordered 
in sequence, while others are left unordered. A manuscript containing a single piece will, for clarity, be called a "single manuscript," forming a separate category.

Format. Most manuscripts are in folio format with sheets in the order of magnitude of $20 \times 30 \mathrm{~cm}$, which corresponds approximately to modern A4 or Letter format. Italian manuscripts tend to be in oblong folio format, while transalpine manuscripts prefer upright folio format, but this distinction is not absolute.

Order. If the sequence of the pieces in the complete manuscripts (or editions) and the ordered complete sets is studied, the first thing to strike one is the variability of the sequences encountered. This is especially true of the pre-publication manuscripts. The first edition reproduces the sequence found in one particular pre-publication manuscript, and this sequence is retained in all the post-publication manuscripts.

Titles. Boccherini's Trios op. 1 appear in the early sources - both manuscript and printed -under various titles. Most frequent is the title "Trio," with "Sonata (a tre)" and "Divertimento" occupying second and third place, respectively. Bailleux introduced the designation "Trietto" for them on the title page of the first edition, employing "Trio" for the individual pieces within the edition. Boccherini later (1796) listed them as "Terzetto."3

Designation of the Violoncello Part. In the sources varying designations are used for the bass instrument of the trios: more precisely, three - "Violoncello," "Basso" and "Violoncello Obbligato."

Order of Movements. The majority of the sources present each trio with the same succession of movements, be this fast-slow-fast or slow-fast-special, where "special" is either a fugue or a Tempo di Minuetto. But a few sources (Ot, Ne) alter the order, especially in the second schema, which is then amended to fast-slow-special.

Tempo Markings. Tempo markings for movements may easily vary among the sources. Sometimes, the variation is rather cosmetic, as in the addition of assai to Largo or Presto, the alternation between spiritoso (or spirituoso) and con spirito (similarly: brioso and con brio) and the omission of "ma" in Allegro ma non tanto. In other instances, the variation is more substantive, as in the replacement of Tempo di Minuetto by Allegro for the last movement of the Trio in $\mathrm{C}$ major in certain sources. Sometimes, there are differences of tempo marking in the different parts for an individual manuscript. All these types of discrepancy are very normal in the transmission of eighteenth-century music.

The Musical Text. What strikes one immediately when the manuscripts transmitting Boccherini's Trios op. 1 are studied is the great variability of musical text among the various sources. No two sources are exactly the same in this respect. This variability concerns all aspects of the composition: both the notes themselves and secondary characteristics such as articulation, dynamics and ornamentation.

Variation in the notes themselves can have different causes. The basic distinction is between errors and variants. We will speak of errors when there are readings that cannot possibly be accepted in a decent performance of the piece: incorrect pitches; incorrect or missing accidentals; incorrect durations; over-long or over-short rests; missing notes;

3 See the thematic catalogue of Boccherini's works that must be a copy of his own autograph catalogue drafted in 1796. On this, see Pascoe, "La reaparición del catálogo de Baillot," 77-90. The page with the six Trios op. 1 is reproduced on p. 83 . 
missing bars, and so forth. Errors occur in greater or smaller numbers in all the sources examined.

We will speak of variants when there are different readings that are all possible musically: different notes chosen for double or triple stops; rhythmic variants; octavetranspositions of motives; extra notes within the same harmony; alternative notes; longer notes instead of repeated notes of shorter duration (or vice versa); tied versus untied notes etc.

Several musical figures appear to be extremely conducive to variants. A particularly common type of variant is what will be called the "dotted figure" (usually on a weak part of the beat or the bar) where parallel passages or other sources give an undotted figure. Sources are highly variable in the notation of these figures. It is almost as if the dotted figure were a realization of the undotted figure making inégalité explicit. Most often, this concerns two semiquavers (realized as a dotted semiquaver and a demisemiquaver); less often, two quavers (equivalent to a dotted quaver and a semiquaver). A similar, but less frequent, source of variability is the dotted figure with two notes for the shorter element, such as a dotted quaver followed by two demisemiquavers. This figure may occur as a variant comprising an undotted quaver followed by two semiquavers.

Other very common variants concern the notes making up double or triple stops. A double or triple stop in one source may appear as a single note or as a different chord in another source.

Highly variable, too, is the tying together (or not) of consecutive notes of the same pitch, either short or long. Some sources tie as much as possible, while other do not trouble to tie at all. In the cases of series of syncopations, the beginnings and endings of ties may differ among the sources. If a tie proceeds from one stave to the next, it usually occurs only at the end of the first stave, not at the start of the next.

It is very common that the notes and rests ending phrases, particularly before a double bar (either the one in the middle of a movement or the one at the end), have different durations. Upbeats are not always subtracted from the final bar of the period.

Articulation. The variability of articulation in early sources is notorious. Consistency in articulation does not exist as a requirement in eighteenth-century manuscript copying procedures.

Dynamics. Even more unreliable than articulation is the notation of dynamics, since these instructions are not directly attached to notes. Dynamics are rarely identical in any two sources.

Ornamentation. Somewhat more faithfully transmitted than articulation or dynamics is ornamentation. Three types can be distinguished: the appoggiatura, the trill and the turn.

Cleffing of the Violoncello Part. Many passages in violoncello parts are written in the tenor clef. Although the various sources largely agree on the desirability of employing the tenor clef, there is some variation in the implementation: the sources do not necessarily change clef in the same place. Some sources use the treble clef with downward octave transposition (the so-called "tenor G" clef) in place of the tenor clef (Gr2, MC, Sto1). Conversely, a source such as Ge2 does not use the tenor clef at all, but instead notates high passages rather awkwardly with a profusion of leger lines.

Abbreviated Notations. In circumstances where the speed of copying and the consumption of paper were important factors, copyists understandably tried to use abbreviated 
forms of notation wherever possible. The most common type of abbreviation takes the form of single notes with a cross-stroke through the stem to represent repeated quavers, or two cross-strokes for repeated semiquavers. These notations are common in nearly all the sources, but their incidence varies considerably.

\section{Types of Copies and Copyists}

If we approach the variability of the sources from the angle of the copyist, it is possible to place the latter in five groups: copyists who merely copied: either (1) from an edition, or (2) from another manuscript; copyists who revised their copy text; copyists who arranged their copy text; copyists who transcribed their copy text for other instruments. Something will be said about each group.

(1) Copyists copying from printed editions. An edition is usually unambiguous and precise in its notation (even if containing errors) and at the same time prestigious as a source. Therefore, copies made from editions are usually similarly precise and do not introduce new variants in the transmission of the works, allowing for occasional errors. Earlier, I introduced the appellation post-publication manuscripts to designate these manuscript copies.

In the case of Boccherini's Trios op. 1 there are not a great many post-publication manuscripts. Through study of their variants they can all easily be linked to one or other of the five early editions of the work.

(2) Copyists copying from other manuscript copies. Manuscripts are rarely totally unambiguous, and rarely so precise in their notation that they induce the copyist to do nothing other than faithfully copy the musical text found therein. Normally, there is some inexactitude and ambiguity in their musical notation, and this fact has consequences for the manuscripts copied from them. The copies are normally not exact reproductions of their sources, but ones that introduce errors, variants, inaccuracies and whatever further differences there may be. Copyists appear to be highly variable with regard to how much articulation, dynamic marking and ornamentation they are willing to insert into their copies. The variants that they introduce in this fashion may be termed random variants.

Most of the pre-publication manuscripts of Boccherini's Trios op. 1 were written by these ordinary copyists. Some of these manuscript copies contain only a few errors and variants; others, many more.

If one could assume that all errors and variants would be retained in successive copies, one might entertain the fond hope that analysis of these errors and variants would enable one to construct a stemma of the sources. In the case of Boccherini's Trios op. 1 this proved impossible, except for certain isolated groups of manuscripts. The two great stumbling blocks are that certain errors and variants may occur in otherwise not directly related sources and that passages may indeed find themselves restored to an earlier state in the process of copying. It may also be that the preserved manuscripts represent too small a portion of the manuscripts that once existed to permit a reliable stemmatic analysis. 
(3) Revising copyists, who did not merely copy the musical text, but also looked at it with an expert eye and introduced improvements, or at least changes that they considered improvements. In this case, one may speak of substantive variants. A copy produced in this manner may be called a revision (or a version, if placed in comparison with an earlier state). If the revised copy itself becomes recopied, this gives rise to a group of similar manuscript copies that differ from the manuscript copies of other groups. Within this group the manuscript copies may differ from one another simply through random variants.

Within the pre-publication manuscripts considered here one may indeed distinguish four versions accommodating three revisions. The first version (as I term it) is the one found mostly in Central-European manuscripts, which may indeed represent the trios as Boccherini originally composed them. The second version (in my nomenclature) exists in a large number of manuscripts both inside and outside Italy, and must be considered a revision of the first version. There are good reasons to assume that these revisions stemmed from the composer, but absolute proof of this cannot be given. The alterations take many forms.

First, there are changes of detail, such as the creation of a dotted figure from two notes of equal duration, the splitting of notes in two or three notes of shorter duration or other small rhythmic changes.

Second, quite a few notes in the Violoncello part were moved up or down an octave. An example occurs in the fugue of the Trio in G major (5/iii/62-63, 70-71, 140-141 and $148-149):^{4}$

First version:

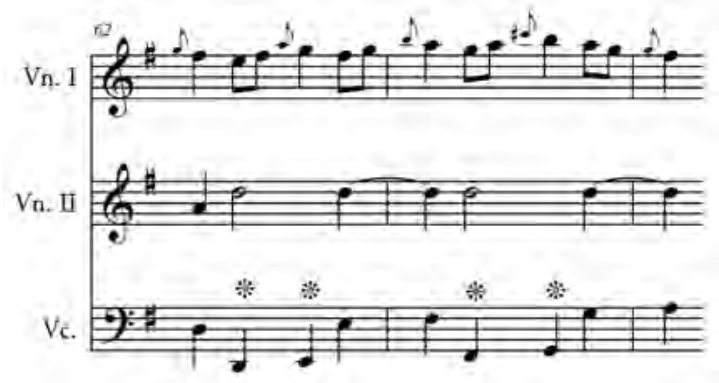

Second and later versions:

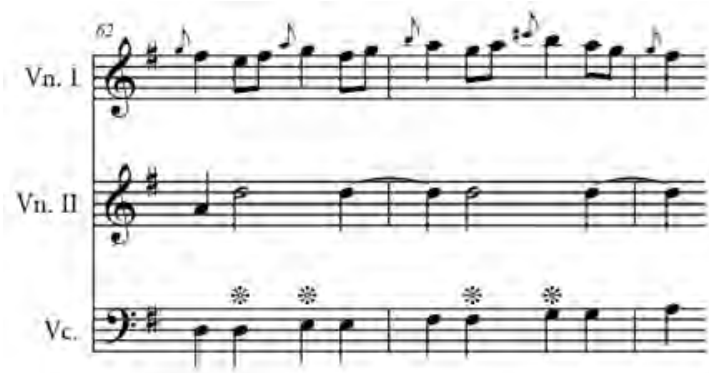

4 The expression "5/iii/62-63" means Trio 5, third movement, bars 62-63. 
Third, in a few instances one of the violin parts was transposed up an octave or even two octaves. The most noteworthy instance occurs in the Trio in F (3/i/55-56), where repeated notes on the pitch $\mathrm{c}^{\prime}$ are transported two octaves higher:

\section{First version:}

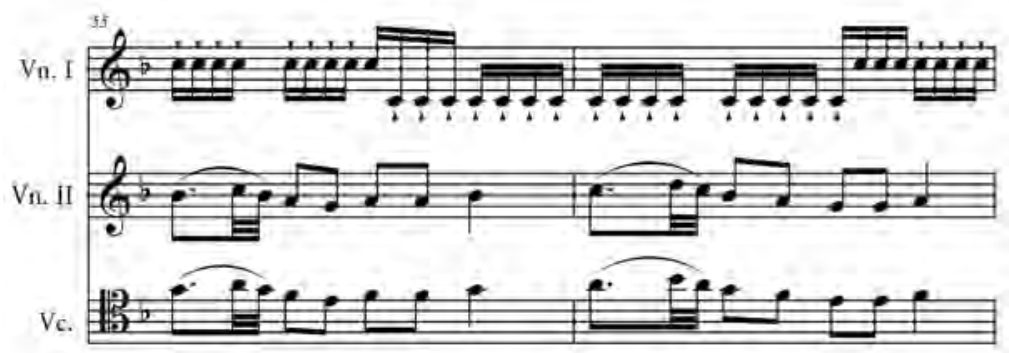

Second and later versions:

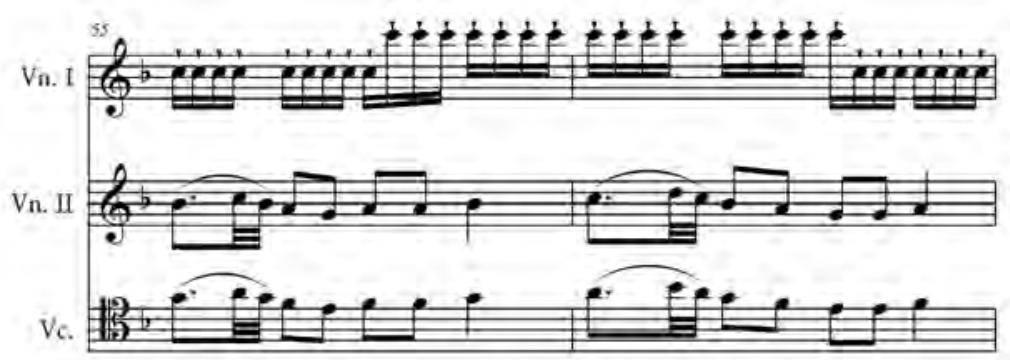

Fourth, there are many instances where double or triple stops were replaced by different double or triple stops or by single notes, or where single notes were replaced by double or triple stops.

Fifth, in a fair number of cases the exact point of insertion of a tenor or bass clef in the cello part was changed.

Sixth, several tempo markings were altered. The notation of the first movement of the Trio in $\mathrm{G}$ major switched from ${ }_{8}^{3}$ to ${ }_{4}^{3}$ metre, with a concurrent adjustment of the tempo marking from Largo to Larghetto.

Then there are, in the seventh place, changes in detail that may be considered genuine compositional improvements. They are perhaps not necessary alterations, but they certainly make the composition run more smoothly. One of them will be illustrated here. The entry of the countersubject of the fugue ending the Trio in D major is made clearer by changing the original semibreve into a minim preceded by a minim rest $(2 / \mathrm{iii} / 1 / \mathrm{Vc}$.): 
First version:

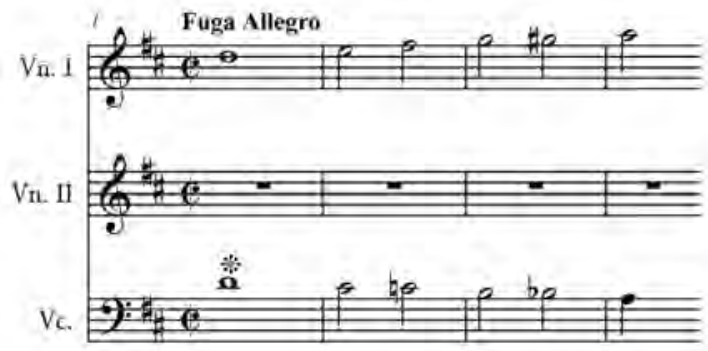

Second and later versions:

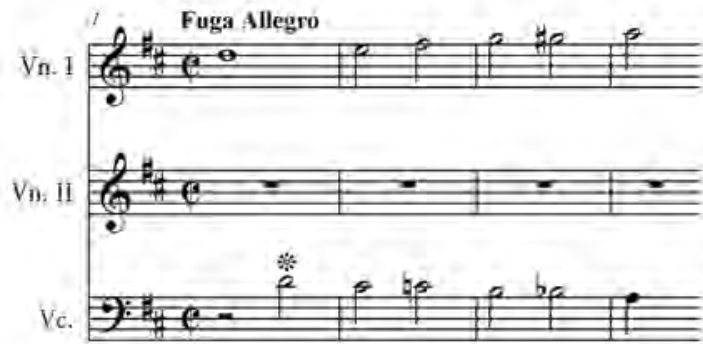

A substantive change in the composition occurs in the third movement of the Trio in A major, where the Violino Secondo and Violoncello parts are freshly composed in an entire bar (bar 27=29, and, similarly, bar 72=74), giving rise to a completely new figure:

First version:

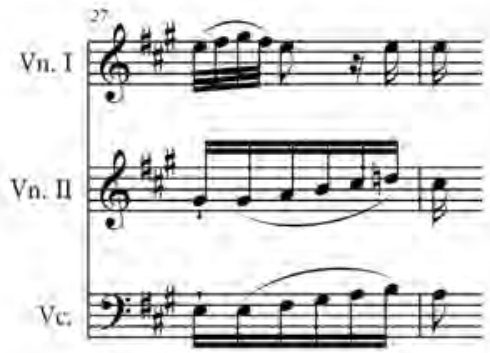

Second and later versions:

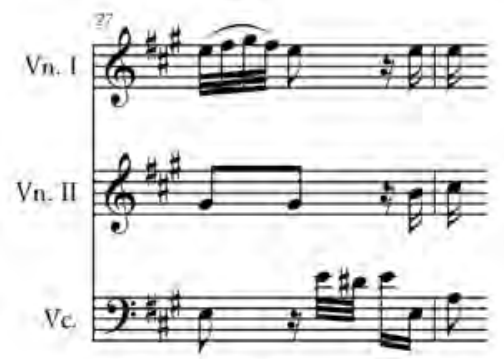

There are also, in the eighth place, a few changes that can be considered rectifications of defects in the composition of the first version: corrections that are necessary or at least desirable. Just one example is given here: bar 26 of the Tempo di Minuetto of the Trio in $\mathrm{C}$ major: 
First version:

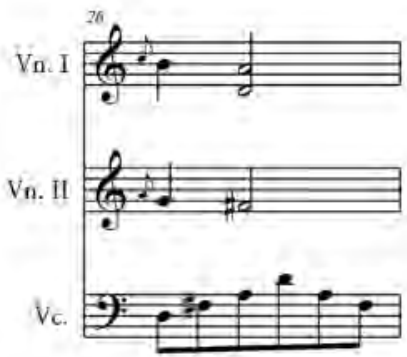

Second and later versions:

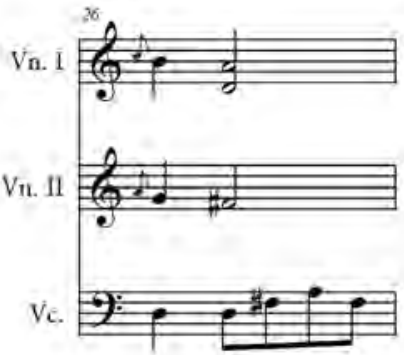

The arrival of the f-sharp in the bass is indeed better delayed until the double suspension has been resolved, and it is similarly an improvement to have a $d$ in the bass at the precise moment of this resolution.

The first edition (Bailleux, 1767) appears to be closely related to one of the pre-publication manuscripts (Ve1) - one that within the category of pre-publication manuscripts is actually somewhat peripheral. This manuscript forms, with some related manuscripts, a kind of subgroup within the category of pre-publication manuscripts: one that may appropriately be dubbed "Adriatic" since all of them are held by libraries in cities on the Adriatic littoral (Venice, Ancona).

After the second version came the third version. The third version is recognizable by a number of variants absent from the first and second versions. A substantive variant occurs in the second movement of the Trio in C major (1/ii/19-27 and 109-116), where the violin parts are transposed down an octave throughout an entire passage:

First and second versions:

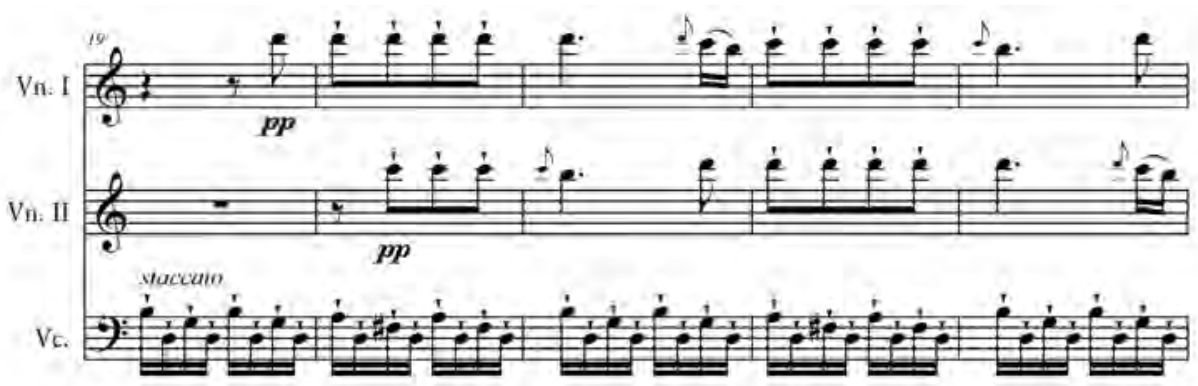




\section{Third version:}

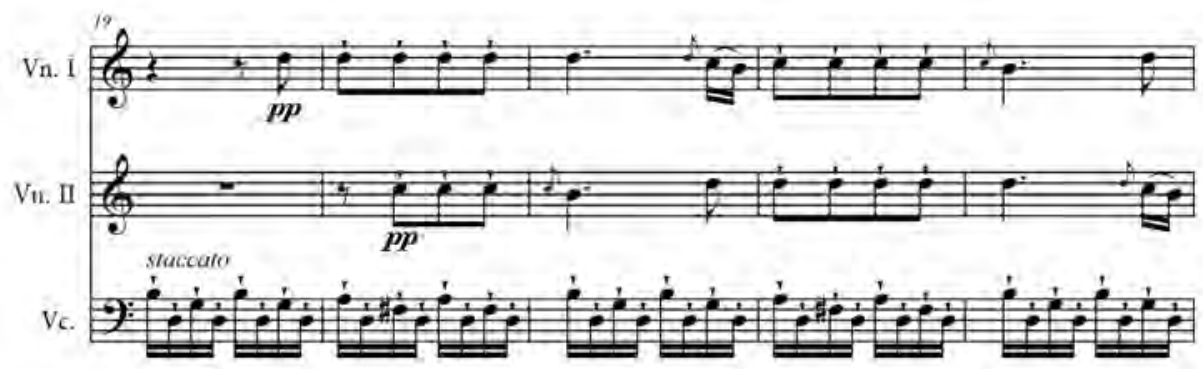

The disparate number of changes among the six trios and, especially, the disparate nature of these changes suggest that this second revision was the work of a copyist who both made some textual alterations and introduced several unintentional mistakes. It seems unlikely that they are the work of Boccherini himself.

A fourth version occurs in the two manuscripts (Berg, Sta) that may likewise be considered to form a subset: the "Alpine" group, named after their present locations (Bergamo, Stams in Austria). The two manuscripts are largely identical, so far as variants are concerned. There are many of these, and many of them are substantive, although unevenly distributed among the six pieces. Here, almost for the first time in the manuscript copying process, we see at work an active and an intelligent copyist: someone who has really tried to improve the pieces, short of arranging them. It is only here that a specific error in the bass of the Presto of the Trio in F major (bar 161/2), present in all the manuscripts discussed so far, has been corrected. An unnecessary inconsistency in the Violino Secondo part of the Trio in B flat major (Presto, bars 89 and 97) has been remedied. Apart from these and some other remarkable interventions, there are numerous minor changes. In particular, the bass line has been modified in many places, but bars in the other parts have also occasionally been recomposed. In view of the appearance of this version in only two rather peripheral sources, it seems improbable that the revision was the work of the composer.

(4) Arranging copyists. In two cases, a copy can aptly be called an arrangement. One manuscript (Pr2) contains an arrangement rather than a straightforward copy of the Trio in G major. Behind this arrangement, however, the First Version of the trio is clearly recognizable, for example through the presence of the Largo in 3/4 metre. The arrangement leaves the composition basically as it is but changes many details. In all three movements there are a few passages that have been replaced by newly composed bars, so that they all have a few bars more or less than the original composition. Articulation, dynamics and ornamentation are less ubiquitous but more consistent than in the average manuscript of the Trios, so the arranger apparently had clear ideas about these aspects.

Another manuscript (An1) contains an arrangement of the Trio in F major. Many passages are almost recomposed. Bar 9 of the Allegro is reduced to a half-bar, which 
means that the barlines of the next 24 bars all shift by a half-bar. This anomaly is rectified at the cadence of the first period, in bar 33, which has become halved as well. There is a cut running from the second half of bar 44 to the first half of bar 48 in the Allegro, where the final cadence is similarly shortened. Conversely, the final cadence of the Largo is extended by a full bar. Numerous changes have been introduced in all parts in all movements. Occasionally, passages for the two violins are exchanged, as occurs in bars 14-17 of the Largo and bars 1-8 and 94-118 of the Presto. The other Trios in the same manuscript exhibit a fair number of variants, but one cannot say they were arranged in the manner of the F major Trio.

(5) Transcribing copyists. One manuscript (Ge7) contains a transcription of the Trio in A major for two flutes and violoncello. The cello part was left untouched, while the two Violino parts needed very little adaptation to the new instruments: double and triple stops are reduced to the highest note; passages with notes lower than $d^{\prime}$ are transposed up an octave.

A manuscript in Stift Engelberg (En) has an added partbook, which writes the bass part in the treble clef, this time not written an octave above sounding pitch but instead a twelfth higher, which transposes the piece to $\mathrm{C}$ major. This notation represents what a performer would do when reading the music as a violinist but playing a violoncello. Perhaps this part was written for a viola da spalla or a viola pomposa, instruments with cello stringing but played in front of or over the shoulder. The Basso partbook of the $\mathrm{C}$ major Trio has the remark "bei diesem muss die Bass mit die [sic] Violen abgespillt werden," which perhaps refers to a performance of this kind. But there is no bass partbook in the treble clef for the $\mathrm{C}$ major Trio to match that for the $\mathrm{F}$ major Trio, as just described.

One manuscript (Na2) has the bass part arranged for double bass ("Controbasso"). The arrangement is rather drastic: where the cello had florid writing in the tenor clef, either melodic or accompanimental, this has been systematically replaced by simple notes and textures in the bass clef or by rests, thus removing many melodic passages played in parallel thirds or sixths with the Violino Primo or Secondo. The remaining double stops in the bass parts are replaced by single notes. Passages featuring broken chords in semiquavers are similarly replaced by simple notes. All signs for articulation, dynamics and ornamentation disappear.

\section{Conclusion}

This overview of the manuscript and printed dissemination of Boccherini's Trios op. 1 tells us in the first place that pieces of music change during the process of their dissemination. Each instance of copying, including publication, may bring with it changes of detail or more substantive changes. Leaving aside copyists working from a printed exemplar, the reproduction of a source exactly as received was not a standard requirement in eighteenthcentury copying practice. Copyists could introduce changes at various levels. They could inadvertently introduce mere random errors and mistakes; they could also create variants, distinguishable from errors through being performable alternatives. Other copyists made 
a habit of revising or (in their eyes) improving the music they copied. And, finally, some copyists transcribed pieces for other instruments or instrumental ensembles.

All these different variations in the copying process are observable in the transmission of Boccherini's Trios op. 1, partly as a consequence of the large number of sources involved. Most important from the point of view of the musician or the musicologist are, of course, the variants and the revisions, the latter arising when the variants are substantive and occur in a number of sources. The question then arises: are these variants and revisions due to the composer or to some zealous copyist? In the case of Boccherini's Trios op. 1 there appear to be four discrete versions, which implies three revisions. Of these revisions, the first may be connected with the composer: there are compositional improvements, and the new version created is found in a large number of sources. The other two revisions, in contrast, seem to be the work of copyists not content merely to reproduce the text of their exemplars.

This article has dealt with musicological problems at two distinct levels. In the first place, it has considered the transmission processes of musical works in general; in the second place, the manuscript and printed dissemination of Boccherini's Trios op. 1 in particular. Each level informs, and benefits from, the other. The terms and associated concepts adopted here to describe the transmission process of music in general are, of course, derived from working with the special case of Boccherini's Trios op. 1. On the other hand, the analysis of a particular case is much easier to undertake when it can be based on concepts borrowed from a more general model.

The concepts and methods used for studying the dissemination of Boccherini's Trios op. 1 can equally well be applied to the study of the dissemination of other collections and works. Such studies are unlikely to parallel in detail the pattern revealed by this study of Boccherini's Opus 1: one should, rather, imagine that each new musical work investigated will have its unique dissemination "profile," albeit one constructed from similar elements.

Table 1 Diagram showing the various categories of sources and the relations between these categories

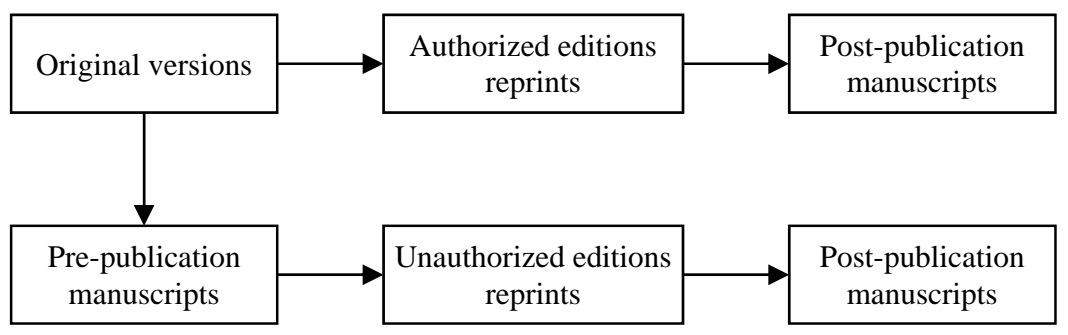


Table 2 Diagram showing the categories of sources in the dissemination of Boccherini's Trios opus 1 (expressions such as "First version" and "Second version" refer to the various textual states of the compositions)

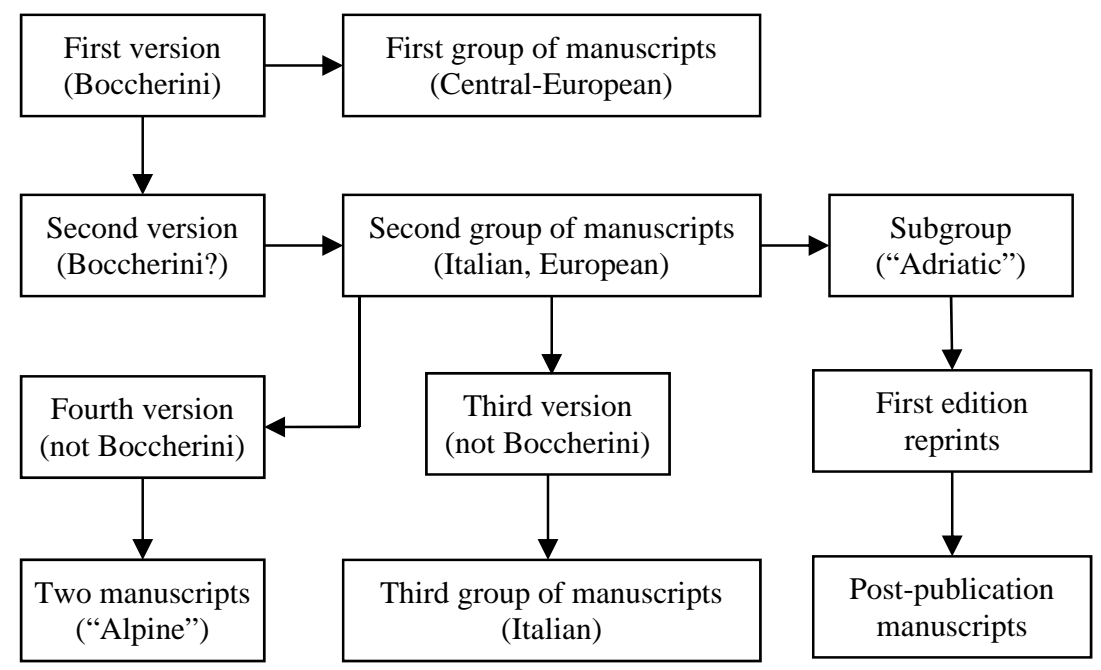

\section{APPENDIX 1}

The six Trios op. 1 in the sequence adopted in Boccherini's Thematic Catalogue:

1. Trio in C major, G. 82

2. Trio in D major, G. 80

3. Trio in F major, G. 77

4. Trio in B flat major, G. 78

5. Trio in $\mathrm{G}$ major, G. 81

6. Trio in A major, G. 79

and in that of the first edition (Paris, Bailleux, 1767):

1. Trio in F major, G. 77

2. Trio in B flat major, G. 78

3. Trio in A major, G. 79

4. Trio in D major, G. 80

5. Trio in $\mathrm{G}$ major, G. 81

6. Trio in C major, G. 82

In order to avoid confusion, it is best to refer to the key of the piece or to the Gérard number rather than to its position within the set of six pieces. 


\section{APPENDIX 2}

Overview of sources of Boccherini's Trios op. 1.

Pre-publication manuscripts:

An1 Ancona, Biblioteca comunale, Ms. mus. 3. All six Trios.

An2 Ancona, Biblioteca comunale, Ms. mus. 6 and 7.

Trios in D major, G major (incomplete).

Berg Bergamo, Biblioteca civica, Ms. D.6.2.2. All six Trios.

Berl1 Berlin, Staatsbibliothek, Mus. ms. 2006/1. Trio in C major.

Berl2 Berlin, Staatsbibliothek, Mus. ms. 2008/2. Trio in G major.

Bo Bologna, Museo Internazionale e Biblioteca della Musica, Ms. DD.183. Trio in D major.

DH Den Haag, Nederlands Muziek-Instituut, Ms. 49 D 21. Trio in D major.

Ei Kloster Einsiedeln, Musikbibliothek, Ms. 69/47 23. Trio in C major.

En Stift Engelberg, Musikbibliothek, Ms A 230-233. Trios in $\mathrm{C}$ major, $\mathrm{F}$ major, A major, B flat major.

Fi Firenze, Conservatorio, Ms D.IX.250-252. Trios in D major, G major.

Ge1 Genoa, Conservatorio, Ms. A.7b.43 (B.1.17). All six Trios. Score.

Ge2 Genoa, Conservatorio, Ms. Q.1a.1.35-37 (A.7.15-17). All six Trios.

Ge3 Genoa, Conservatorio, in Ms. SS.A.1.8 (G 7) and Ms. SS.A.2.13. Trios in C major, F major, B flat major.

Ge4 Genoa, Conservatorio, in Ms. SS.A.1.22 (G 8). Trios in A major, D major, C major, F major.

Ge5 Genoa, Conservatorio, in Ms. SS.A.1.8 (G 7). Trio in D major.

Ge6 Genoa, Conservatorio, in Ms. SS.A.1.8 (G 7). Trio in G major.

Ge7 Genoa, Conservatorio, in Ms. SS.A.1.8 (G 7). Trio in A major, in an arrangement for two flutes and violoncello.

Gr Graz, Diözesanarchiv, Ms. 506, 510-513. Trios in A major, B flat major, F major, D major, C major.

He Heiligenkreuz, Stiftsbibliothek, Ms. VI b 1. Trio in A major.

Le Leipzig, Musikbibliothek, Ms. Becker III.1.1.29. Trio in D major.

Ma Madrid, Real Conservatorio Superior de Música, Ms. 1/7041-11. Trio in F major.

Mi1 Milan, Conservatorio, Mss. Noseda E 24.33. Trio in C major.

Mi2 Milan, Conservatorio, Ms. Da Camera 3/6. Trio in C major.

Mi3 Milan, Conservatorio, Ms. Da Camera 3/12. An arrangement of the Trio in B flat major.

MC Montecassino, Archivio dell'Abbazia, cod. music. All six Trios. Score.

MT Montecatini Terme, Biblioteca Comunale, Fondo Venturi, Ms. A.1a-f. All six Trios.

Na1 Naples, Conservatorio, Ms. 22.5.6. All six Trios.

Na2 Naples, Conservatorio, Mus. Str. 437-439. All six

Trios, with the bass part for "Controbasso". 
Ne1 Neckarzimmern, Burg Hornberg, Mss. H 18-23. All six Trios.

Os Ostiglia, Biblioteca Musicale, Mss. Mus. B 3079. Trio in G major.

Ot Ottobeuren, Benediktiner Abtei, MO 133-137. Trios in

F major, B flat major, G major, C major, A major.

Par1 Paris, Bibliothèque nationale de France, Musique, Ms. Vma 69. All six Trios.

Par2 Paris, Bibliothèque nationale de France, Musique,

Ms. D 10760. Trios in F major, A major.

Pr1 Prague, Národní Museum, Mss. XXII B 44-49. All six Trios.

Pr2 Prague, Národní Museum, Mss. XXIII A 506-507.

Trios in $\mathrm{G}$ major (an arrangement.), C major.

Pr3 Prague, Národní Museum, Ms. XLI B 341. Trio in G major.

Pr4 Prague, Národní Museum, Ms. XLI B 342. Trio in F major.

Pr5 Prague, University Library, Mss. 59 R 3568, 3529, 3544, 3549, 3550, 3551. All six Trios.

Rh1 Rheda, Bentheim-Tecklenburgische Musikbibliothek (in Münster, Universitätsbibliothek, Musiksammlung), Mss. 73-75. Trios in A major, B flat major, $\mathrm{C}$ major.

Ro1 Rome, San Giovanni in Laterano, Ms. Mus. C.6a-c. Trio in D major, B flat major, G major (all incomplete).

Sta Stams, Zisterzienser Stift, Musikarchiv, Mus. Ms. 174, 181-185. All six Trios.

Sto1 Stockholm, Musik- och Teaterbiblioteket, in Ms. W3-R. All six Trios.

Sto2 Stockholm, Musik- och Teaterbiblioteket, in Ms.

W3-R. Trios in B flat major, F major.

Sto3 Stockholm, Musik- och Teaterbiblioteket, in Ms. W3-R. Trio in A major.

Ve1 Venice, Conservatorio, Ms. Giustiniani B. 20. n. 2. All six Trios.

Ve2 Venice, Conservatorio, Ms. Correr, B 81, nos. 6, 8, 9, 10, 12.

Trios in $\mathrm{C}$ major, D major, F major, A major, B flat major.

Vi Vienna, Archiv, Bibliothek und Sammlungen der Gesellschaft der Musikfreunde in Wien, Inv. no. IX-2020. All six Trios.

Wo Wolfenbüttel, Staatsarchiv, Ms. 46 Alt 577. Trio C major.

Za Zagreb, Croatian Musical Institute, Algarotti

Collection, Ms. XLIII.W. Trio in C major.

\section{Early editions:}

Ba Sei trietti per due violini, et basso [...] Opera II (Paris: Antoine Bailleux, [1767]), RISM B 3056.

Br Six Sonatas for Two Violins, and a Violoncello Obligato [...] Opera II (London: Robert Bremner, [1769]), RISM B 3057.

Hu Six trios à deux violons et violoncello obligé [...] Oeuvre quatrième (Amsterdam: Johann Julius Hummel, [1771]), RISM B 3034.

Pr Later issue of Br. (London: Preston \& Son [ca. 1795]), RISM B 3059.

Im Sei trietti per due violini, et basso [...] Opera II (Paris: Jean-Jerôme Imbault, [ca. 1810]), RISM B 3058. 
JC Collection des Trios de Boccherini: Premier Livre, Pour Deux Violons et Basse (Paris: Pierre-Honoré Janet \& Alexandre Cotelle, [ca. 1824]), RISM B 3097.

Co Later issue of Pr. (London: Robert Cocks, [ca. 1870]), not in RISM.

Post-publication manuscripts:

Berl3 Berlin, Staatsbibliothek, M 615, 616, 617. Trios in C major, D major, F major. After Ba.

Dr Dresden, Sächsische Landesbibliothek - Staats- und Universitätsbibliothek, Mus. 3490/P/2. All six Trios. Score. After Hu.

Hä Härnosand, Länsmuseet, no shelfmark. All six Trios. After Hu.

Ka Karlstad, Stadsbibliotek, no shelfmark. All six Trios. After Hu.

Pad Padua, Conservatorio, Ms. rari 1/III/24. All six Trios. After Br.

Par3 Paris, Bibliothèque nationale de France, Musique, Ms.

Cons. L. 87 (1-3). All six Trios. After Ba.

Par4 Paris, Bibliothèque nationale de France, Musique, Ms. D. 10774. Trios in D major, B flat major, A major. After Ba.

Ro2 Rome, Accademia di Musica, Ms. A-Ms-3197-3199. All six Trios. After Br.

Sk Skara, Stifts- och Landsbiblioteket, Ms. 416. Movements from all six Trios. After Hu.

Sto4 Stockholm, Musik- och Teaterbiblioteket, Ms. in Collection Wallenberg. All six Trios. After Hu. 


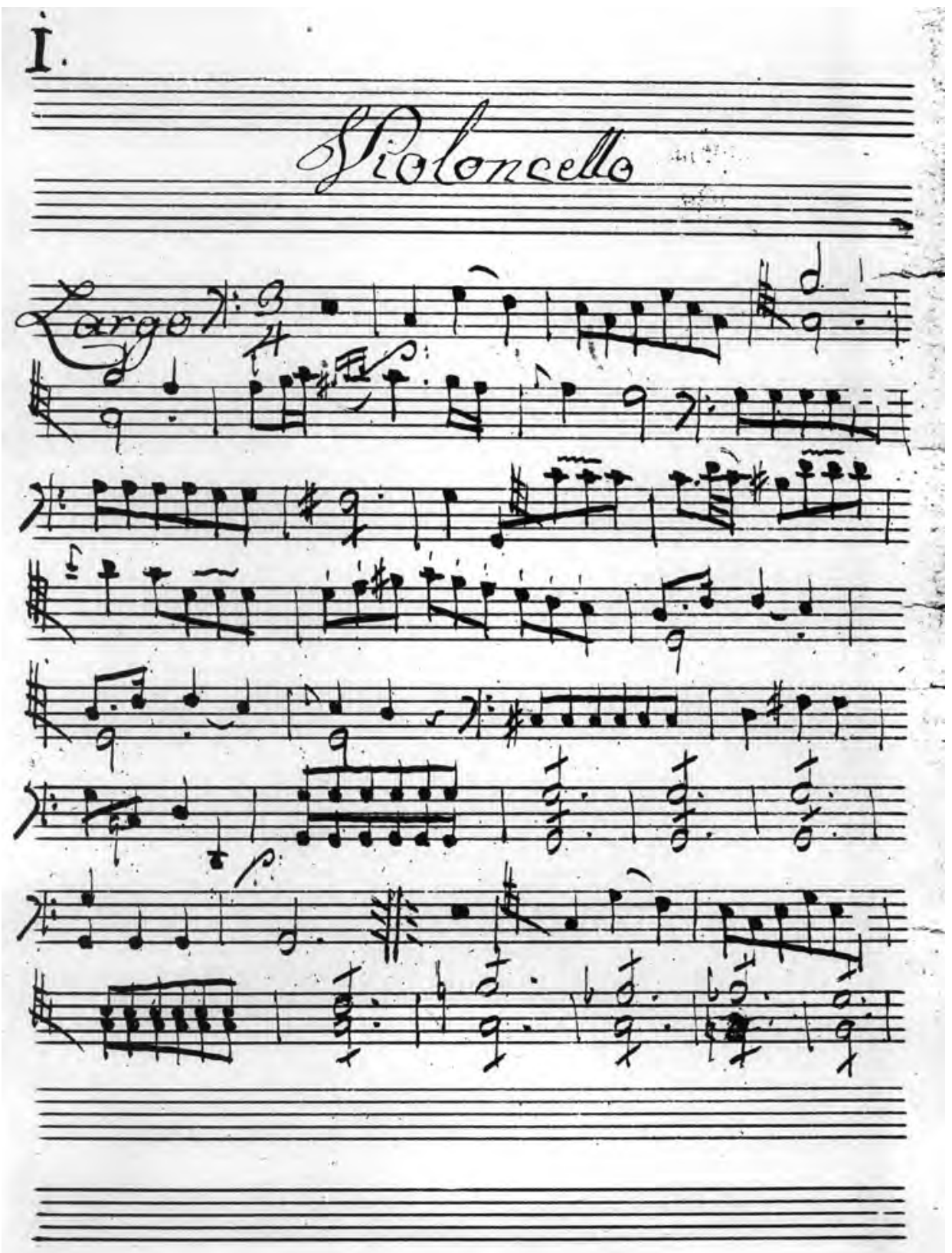

Figure 1 First page of the Violoncello part of Boccherini's Trio in C major, op. 1, no. 1, G. 82 (Vienna, Archiv, Bibliothek und Sammlungen der Gesellschaft der Musikfreunde in Wien, Inv. no. IX-2020; reproduced with kind permission). 


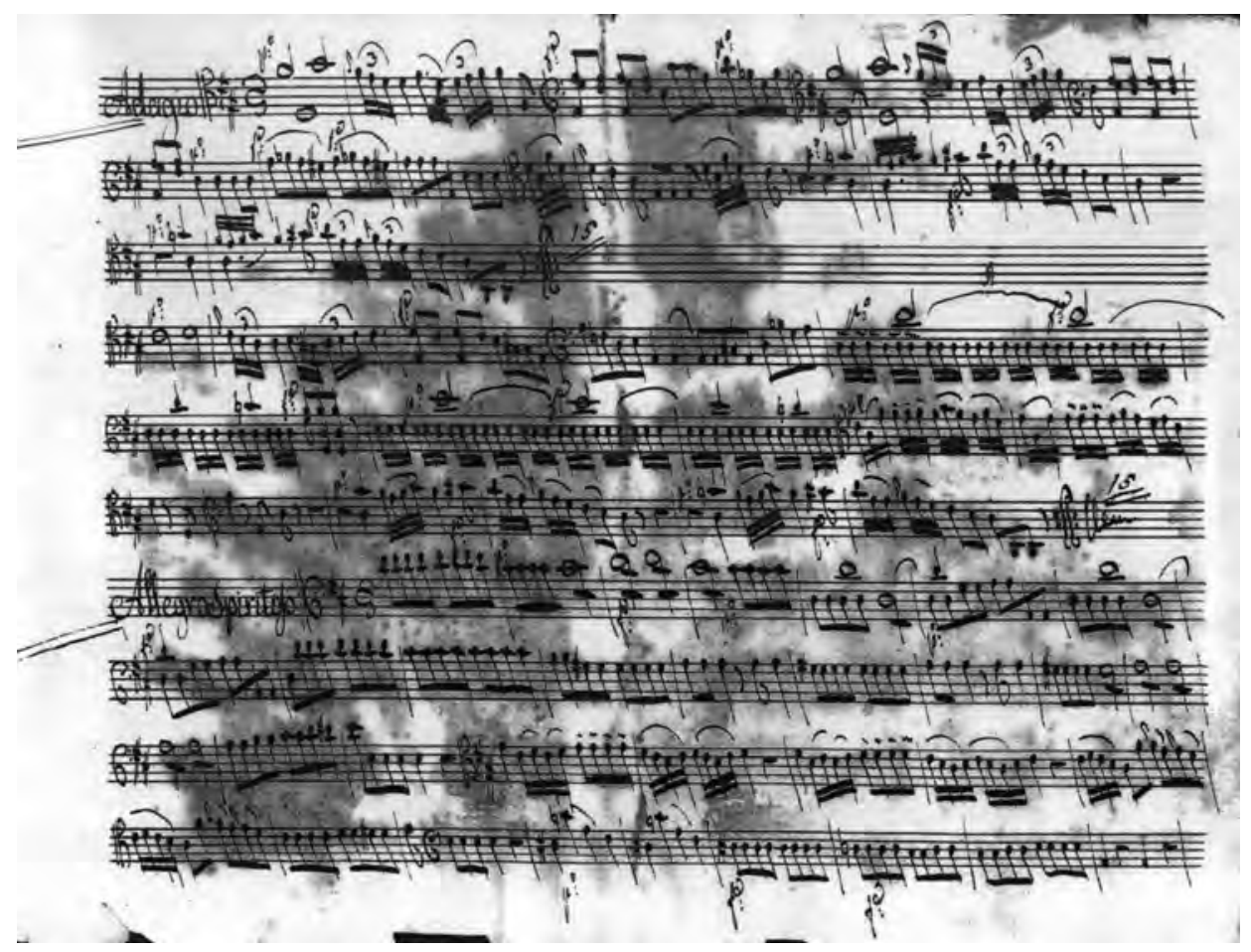

Figure 2 First page of the Violoncello part of Boccherini's Trio in D major, op. 1, no. 2, G. 80 (Montecatini Terme, Biblioteca Comunale, Fondo Venturi, Ms. A.1a). 


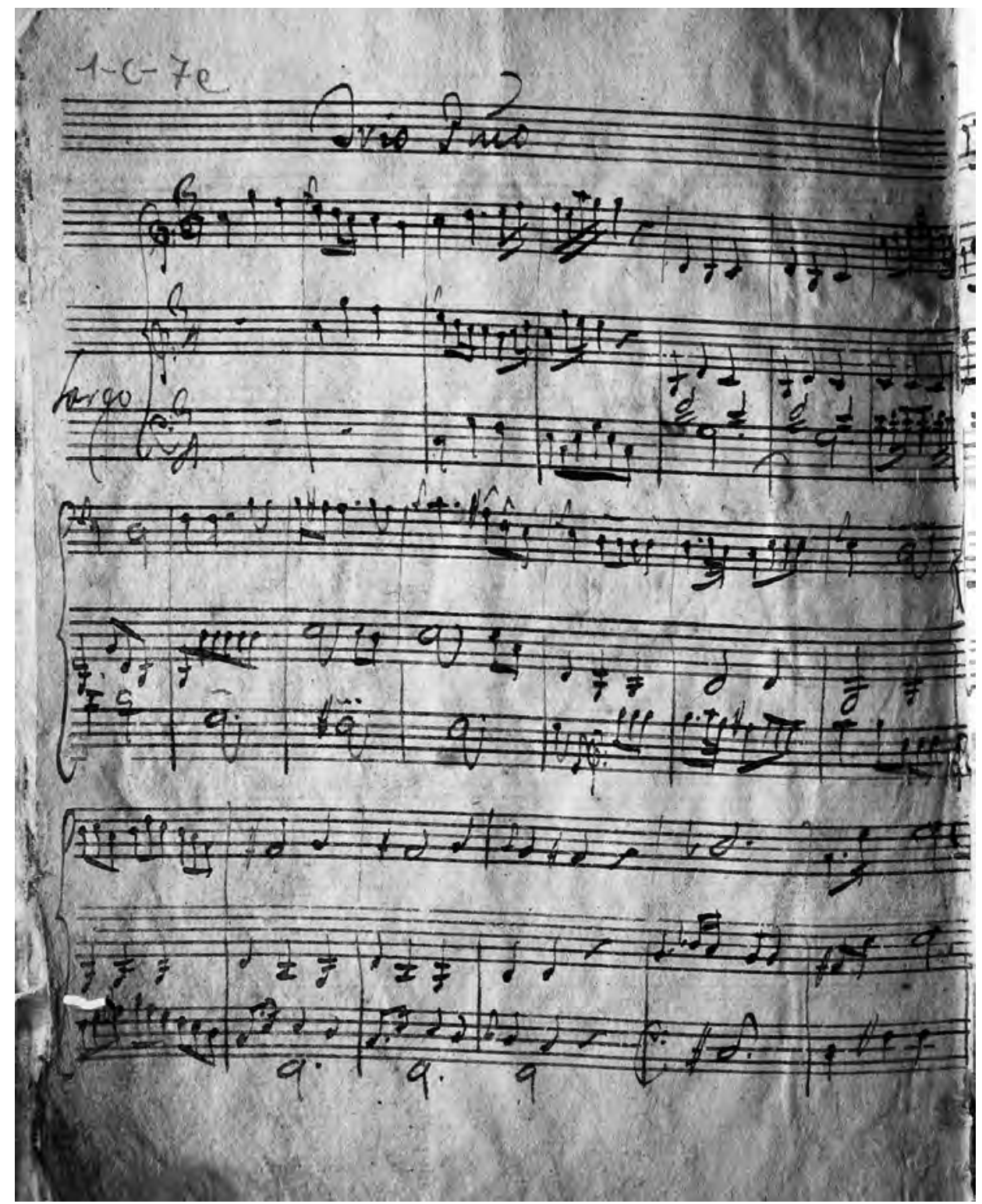

Figure 3 First page of the score of Boccherini's Trio op. 1, with the opening bars of Trio in C major, op. 1, no. 1, G. 82 (Montecassino, Archivio dell'Abbazia, cod. music. I-C-7; reproduced with kind permission). 


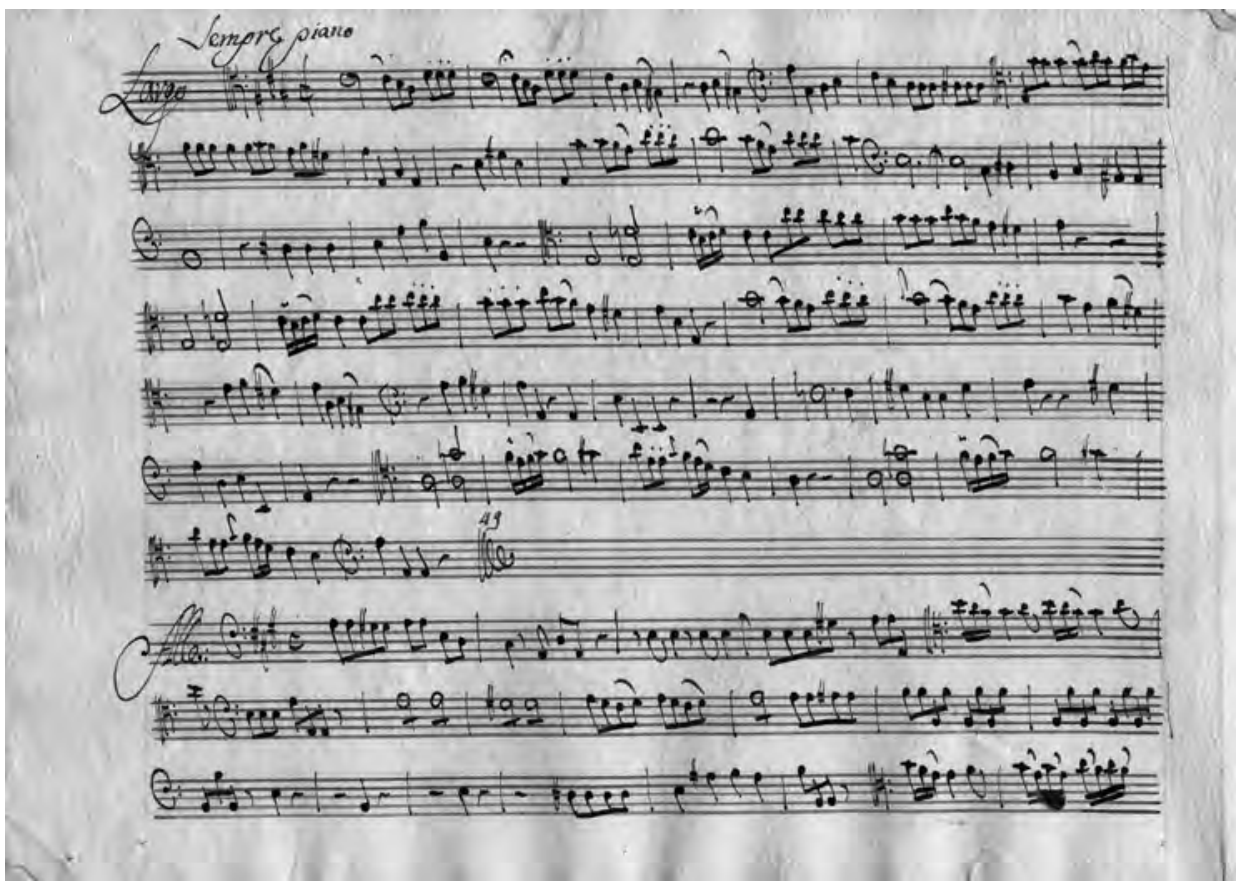

Figure 4 First page of the Violoncello part of Boccherini's Trio in A major, op. 1, no. 6, G. 79 (Stams, Zisterzienser Stift, Musikarchiv, Mus.ms. 174; reproduced with kind permission).

\section{Bibliography}

Boccherini, Luigi. Sei Trii per Due Violini e Violoncello Opus 1 G 77-82. Edited by Rudolf Rasch. Luigi Boccherini Opera Omnia, volume 27.1. Bologna: Ut Orpheus, 2014.

Gérard, Yves. Thematic, Bibliographical and Critical Catalogue of the Works of Luigi Boccherini. Translated by Andreas Mayor. London: Oxford University Press, 1969. Pascoe, Keith. "La reaparición del catálogo de Baillot: un eslabón perdido en la transmissión temprana de los catálogos de la música de L. Boccherini." In Luigi Boccherini: estudios sobre fuentes, recepción e historiografía, edited by Marco Mangani, Elisabeth Le Guin and Jaime Tortella. Madrid: Comunidad de Madrid, 2006. 


\section{STRATEGIJA RAZŠIRJANJA ROKOPISNIH PREPISOV TRIOV OP. 1 LUIGIJA BOCCHERINIJA}

\section{Povzetek}

Čeprav Boccherinijevi Trii op. 1 za dve violini in čelo iz leta 1760 danes ne sodijo med njegova najbolj znana dela, so bili v 18. stoletju med njegovimi najbolj razširjenimi deli. Nič manj kot 60 ohranjenih glasbenih rokopisov pred letom 1830 vsebuje eno ali več tovrstnih Boccherinijevih del. Večino teh predstavljajo rokopisi pred objavo, ki so bili neposredno ali posredno prepisani iz skladateljevih izvirnikov, brez posredništva tiskane izdaje. Prva izdaja je bila natisnjena v Parizu leta 1767, potem pa še večkrat ponatisnjena v Parizu, Londonu in Amsterdamu. Rokopise, ki so bili prepisani iz le-teh, avtor imenuje po-izdajni rokopisi.

Kljub številnim virom raziskovalcu ohranjenost teh del predstavlja veliko težavo. Ohranjen ni noben avtograf ali podoben prepis, niti ni avtoriziranih prepisov. Prva izdaja je nastala na podlagi rokopisov, ki so bili takrat na voljo. Današnji viri zato kažejo izjemno raznolikost prepisov istih glasbenih del. Razlike so vseh možnih vrst: oblike samega vira (partitura nasproti ločeno zapisanim posameznim glasovom), zapovrstnost del, naslovi, opisi parta za violončelo, ključi glasu za violončelo, sosledje stavkov, oznake za tempo, artikulacijo, dinamiko, okraske, pa okrajšave v notaciji in ne nazadnje glasba sama.

Za rekonstrukcijo Boccherinijeve prvotne oblike je potrebna podrobna raziskava vseh virov. Tradicija rokopisnih virov kaže, da so imeli prepisovalci za izdelavo kopij zelo različne strategije. Tisti, ki so prepisovali iz tiskov, so skoraj v vseh pogledih zvesto sledili predlogi; že zaradi samega prestiža izdaje in jasno zabeležene notacije. Tisti, ki so delali na podlagi rokopisov, so imeli na razpolago kopije, ki niso imele prestižnosti tiskane izdaje in so bile navadno površno napisane. Te tako niso mogle biti zelo zanesljive za izdelavo novega prepisa. Prepisi iz rokopisnih virov zato skoraj praviloma prinašajo različice in napake. O različicah lahko seveda govorimo, ko je zapisana drugačna, a izvedljiva oblika glasbenega teksta, napaka pa je tak zapis, ko zapisana oblika povzroča težavo pri izvedbi, na primer manjkajoči takt ali povsem jasna napačna nota.

Le manjši del rokopisnih prepisov iz Boccherinijevega op. 1 vsebuje naknadne popravke $\mathrm{v}$ glasbenem delu: zavestne in resne spremembe prvotno zapisanega, ki so namenjene izboljšavi skladbe. Še korak dlje od izvirnika pa so tisti rokopisi, v katerih je glasba prirejena do te mere, da je na tak način nastala nova skladba.

$\mathrm{Na}$ koncu lahko ugotovimo, da so nekateri prepisovalci izdelali tudi transkripcije za druga glasbila. Rokopisno izročilo Boccherinijevih Triov op. 1 sestavljajo tri oblike prepisov, od katerih vsako opredeljuje prisotnost ali odsotnost številnih različic. Predpostavljamo lahko, da gre za tri faze revidiranja, od katerih bi lahko prvo opravil sam Boccherini, drugo in tretjo pa zagotovo ne. Prepisovalci, ki so skušali zapis popraviti, so sprožili vrsto priredb in transkripcij za druga glasbila, od katerih nobena ne izhaja neposredno iz skladateljevega izvirnega zapisa.

Zgodovina razširjanja Boccherinijevih Triov op. 1 jasno pokaže, da je glasba s prepisi doživela veliko sprememb, vsaj v podrobnostih, do še posebno velikih razhajanj pa je prišlo pri prepisovanju iz rokopisnih virov, saj so imeli kopisti navado tako glasbo revidirati, prirejati in transponirati. 